\title{
Posterior Reversible Encephalopathy Syndrome in severe preeclampsia: case report and literature review
}

\author{
Ağır preeklampside Posterior Reverzibl Ensefalopati Sendromu: olgu sunumu ve \\ literatürün gözden geçirilmesi
}

\author{
Banu Kumbak Aygün ${ }^{1}$, Yakup Baykuş ${ }^{1}$, Said Berilgen², Burçin Kavak ${ }^{1}$, Hüsnü Çelik ${ }^{1}$, Bilgin Gürateş ${ }^{1}$ \\ ${ }^{\prime}$ Department of Obstetrics and Gynecology, Medical School, Firat University, Elazig, Turkey \\ ${ }^{2}$ Department of Neurology, Medical School, Firat University, Elazıg, Turkey
}

\section{Abstract}

\begin{abstract}
We describe a 23 year old primigravid patient with severe preeclampsia complicated by posterior reversible encephalopathy syndrome (PRES), who presented with sensory and motor deficits and amnesia in the postpartum period Cranial magnetic resonance imaging (MRI) showed abnormal areas in the white matter of bilateral parieto-occipital lobes, indicating brain edema which disappeared completely on the follow-up scan taken four weeks after delivery together with complete symptom regression. The development of PRES in preeclampsia is discussed and the importance of prompt postpartum blood pressure control is emphasized.
\end{abstract}

(J Turkish-German Gynecol Assoc 2010; 11: 216-9)

Key words: Posterior reversible encephalopathy syndrome (PRES), preeclampsia, pregnancy

Received: 5 February, 2010

Accepted: 29 March, 2010
Özet

Bu yazıda 23 yaşında, ilk gebeliği olan şiddetli preeklamptik bir hastada postpartum dönemde duyusal ve motor sinir bulguları ve unutkanlık ile ortaya çıkan bir posterior reverzibl ensefalopati sendromu (PRES) sunulmuştur. Kranyal manyetik rezonans görüntüleme (MRI) ile bilateral parieto-occipital loblarda beyin ödemine işaret eden anormal alanlar görülmüş olup, doğumdan dört hafta sonra kontrol amaçlı yapılan görüntüleme testi ile bu lezyonların tamamen kaybolduğu ve semptomların da gerilediği tespit edilmiştir. Preeklampside PRES gelişimi tartışılarak, bu hastalarda postpartum kan basıncı kontrolünün önemi vurgulanmıştır.

(J Turkish-German Gynecol Assoc 2010; 11: 216-9)

Anahtar kelimeler: Posterior reverzibl ensefalopati sendromu (PRES), preeklampsi, gebelik

Geliş Tarihi: 05 Şubat 2010

Kabul Tarihi: 29 Mart 2010

\section{Introduction}

Posterior reversible encephalopathy syndrome (PRES), also termed reversible posterior leukoencephalopathy syndrome, is a newly recognized syndrome affecting predominantly the white matter of the posterior cerebral hemispheres (1). Preeclampsia/eclampsia and HELLP syndrome are the obstetric pathologies most related to PRES (1-4). Other associated conditions are hypertensive encephalopathy, renal failure with hypertension, following immunosuppressive or anticancer treatment, autoimmune connective tissue diseases, thrombotic thrombocytopenic purpura, HIV syndrome, acute intermittant porphyria, organ transplantatio and hypercalcemia (1, $5,6)$. The triggering event for this syndrome seems to be an abrupt increase in blood pressure leading to an acute disruption of the blood-brain barrier. However, cases in normotensive patients have also been reported $(6,7)$. This syndrome is characterized by symptoms such as acute-onset headache, altered consciousness, visual disturbances, seizures and occasionally focal neurologic signs $(1,7,8)$. Cranial magnetic resonance imaging (MRI) and computerized tomography (CT) show diffuse abnormalities due to vasogenic edema predominantly within the territories of the posterior circulation and primarily affecting the subcortical white matter of the parieto-occipital lobes (1). This pathology was reported to be mostly reversible, however, in cases of delayed treatment, permanent cerebral injury might occur $(1,5-7)$.

In this paper, we report the case of a severe preeclamptic patient who had postpartum PRES with atypical symptoms of numbness and weakness in the upper extremity, inability to walk by herself and amnesia. This case is important as it illustrates that the symptoms might be varied and atypical in PRES. The neuroimaging findings, management and followup examinations in the patient were presented together with a literature review.

\section{Case Report}

Mrs. G.C., a 23-year-old primigravida presented with increased blood pressure and vaginal fluid leakage at the 36th gestational week. She stated that she did not come regularly for routine antenatal examinations. Her blood pressure on admission was 140/80 mmHg and initial laboratory tests were normal except for mild proteinuria $(1+)$. As the amniotic 
fluid volume was observed to be significantly decreased on ultrasound and the fetal biometric values were compatible with 32 gestational weeks, labor was induced. During labor, the blood pressure began to show elevations up to $160 / 110 \mathrm{mmHg}$ values. When the body temperature increased $\left(39^{\circ} \mathrm{C}\right)$ together with leukocytosis $\left(22.500 / \mathrm{mm}^{3}\right)$ and blood pressure values of $\geq 160 / 110 \mathrm{mmHg}$,the decision to deliver by cesarean section was taken. She delivered a baby boy with 1 and 5 minute apgar scores of 5 and 8, weighing 2300 gr. No problem occurred during the cesarean section. On the first postpartum day, blood pressure values of $160 / 110 \mathrm{mmHg}$ were seen occasionally and treatment with nifedipine was given. Although typical HELLP did not develop, mild decreases and elevations were seen in some of the blood tests; her platelet values decreased to $150.000 / \mathrm{mm}^{3}$, aspartate aminotransferase (AST) increased to $51 \mathrm{U} / \mathrm{L}$, and lactate dehydrogenase (LDH) increased to 393 U/L. Magnesium sulphate i.v. infusion therapy at $2 \mathrm{~g} /$ hour for eclampsia prophylaxis was started during labor and continued in the postpartum period for 24 hours. Fever did not continue in the postpartum period. About 30 hours after delivery by cesarean section, the patient complained of sudden weakness and numbness in the left upper extremity. A neurological problem was suspected and a neurology consultant physician was called. The consultant ordered a cranial MRI which showed T1-weighted hypointense and T2-weighted hyperintense areas in the bilateral parieto-occipital lobes indicating brain edema (Figure 1a). Visual evoked potentials were evaluated which were found to be normal. MR venography was also performed which revealed no pathology. Treatment with i.v. 20\% mannitol 4x100cc/day and i.m. dexamethasone 4x2mg/day were started. On the second postpartum day, blood pressure values were around 140/80 mmHg and platelets increased, and AST and LDH values decreased. However, the patient's complaints increased, she stated that she could not comb her hair, and on the next day amnesia developed together with inability to walk

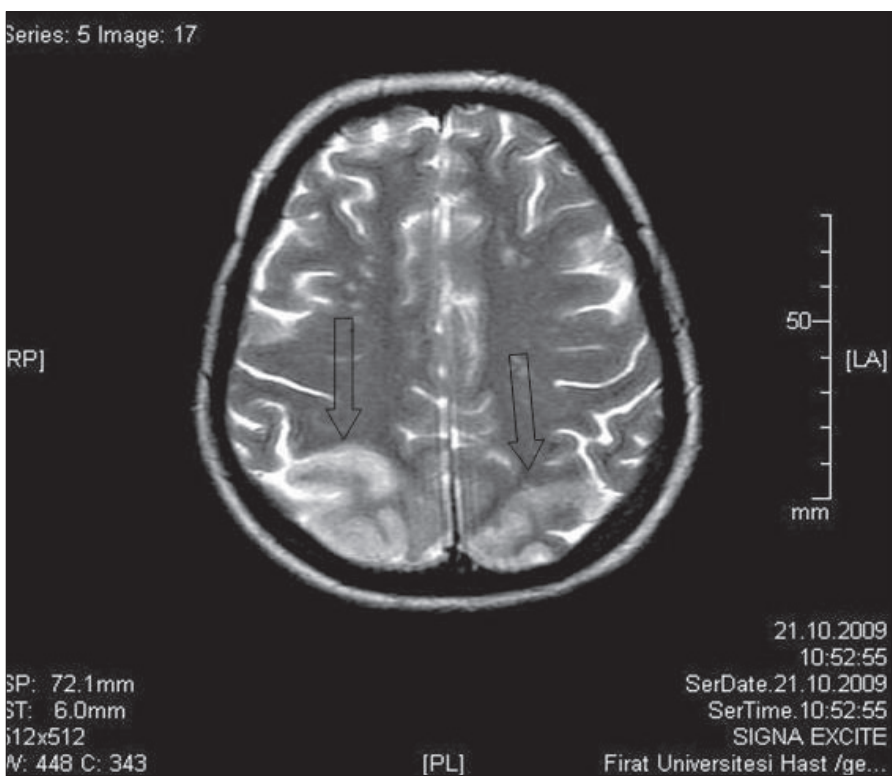

Figure 1a. Shows areas of high signal intensity bilaterally in the parieto-occipital white matter which are consistent with vasogenic edema (arrows) by herself. A cranial CT scan performed on the fourth postpartum day showed bilateral low-density areas involving the white matter of the posterior parietal lobe, being more prominent on the right. Cerebral ischemia with subacute infarction was the diagnosis. Low molecular weight heparin $2 \mathrm{x} 0.4 \mathrm{cc} /$ day and aspirin $100 \mathrm{mg} /$ day were added to dexamethasone treatment and mannitol was stopped. Her weakness and numbness resolved two weeks after delivery and she was discharged with acetylsalicylic acid $300 \mathrm{mg}$ daily treatment. The follow-up cranial MRI obtained four weeks after delivery revealed almost complete resolution of the lesions (Figure 1b). On neurological examination four weeks after delivery, she had neither motor nor sensory deficit but complained of intermittent amnesia.

\section{Discussion}

We describe the case of severe preeclampsia complicated by clinical and neuroradiological findings consistent with PRES. The cause of PRES is multifactorial, but common precipitants in obstetrics are acute elevation of blood pressure and fluid retention. The mechanism of PRES is probably a brain-capillary leak syndrome related to hypertension, fluid retention, and damage to vascular endothelium. PRES has been described as a puerperal clinicoradiologic entity. Prompt diagnosis of PRES is important, as rapid blood pressure reduction resolves clinical and imaging findings in that pathology.

Hypertension associated with fluid overload in patients with an altered blood-brain barrier best explains the acute, reversible white-matter changes that characterize PRES. In a healthy subject, cerebral autoregulatory mechanisms that have both myogenic and neurogenic components maintain constant brain perfusion (9). The effectiveness of the neurogenic component of autoregulation is directly proportional to the degree of sympathetic innervation. To maintain constant cerebral blood flow, cerebral vasoconstriction occurs in response to hypertension,

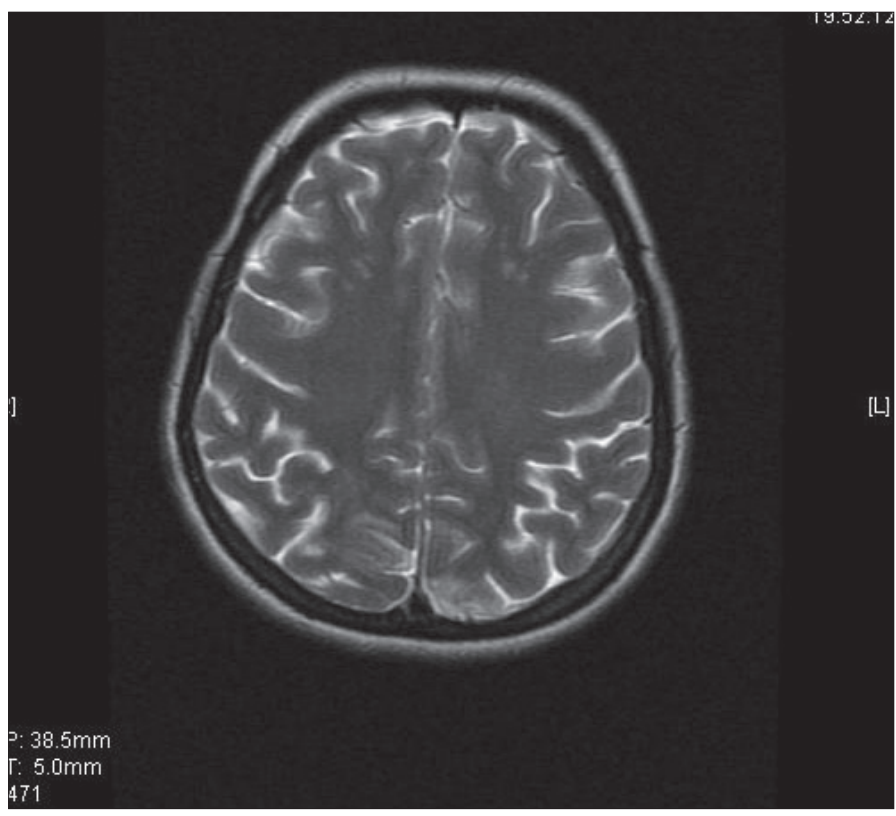

Figure 1b. The follow-up image obtained four weeks after delivery which shows that the abnormalities have disappeared 
normally via sympathetic innervation. In patients with PRES, sudden elevations in blood pressure overcome the autoregulatory capability of the brain vasculature, leading to abrupt dilatation of cerebral arterioles with resultant hyperperfusion. This event also causes breakdown of the blood-brain barrier with focal transudation of fluid into the interstitium and petechial hemorrhages, which is detected as vasogenic edema (8-10). This vasogenic edema is mainly observed in the white matter of the parieto-occipital regions (1). This preference for the posterior brain regions was proposed to be the result of relatively reduced sympathetic innervation of the vertebrobasilar circulation $(8,11)$. However, in some cases the protective sympathetic mechanism of the anterior cerebral vessels may also be overcome (12).

The most common abnormality on neuroimaging in PRES was edema involving the white matter, especially in the parieto-occipital regions. In a recent study, vasogenic edema was reported to be seen in the parietal or occipital regions in $92 \%$ of the 136 patients, but involvement of other brain regions in patients with PRES, such as the temporal lobes, brain stem, cerebellum, basal ganglia, and frontal lobes, has also been reported $(13,14)$. Therefore awareness of variations is important to recognize PRES. In the present case, abnormal signal intensity areas in the bilateral parieto-occipital regions, which are the most commonly involved areas of the brain, were seen on both MRI and CT scans.

PRES is a remarkably heterogeneous disorder, the symptoms and signs of which depend on the involved area of the brain, together with the severity and extent of involvement. Among various symptoms and signs, the most common ones are headache, altered alertness, seizures, confusion, and abnormalities of visual perception. The mental functions might be slowed, spontaneity decreased, and responses slowed. Although severe amnesia is unusual, memory and the ability to concentrate might be impaired,. Some patients have weakness and incoordination of the limbs. Similarly, in this case, numbness, weakness, inability to walk and amnesia developed in the postpartum period. Cases of PRES in the postpartum period with different syptomatology have been reported in the literature. Striano et al. (2) reported two patients with PRES during the postpartum period who had eclampsia and chronic epilepsy which developed as a sequel (2). In another paper, two patients were described who experienced PRES in the late postpartum period without classical preeclamptic signs but with impairment of consciousness and epileptic seizures (15). PRES should be considered in the differential diagnosis of postpartum seizures (16). In our case no seizure or loss of consciousness occurred. Sudden weakness and numbness in the left upper extremity appeared initially. Therefore this case is important as it illustrates atypical symptoms in PRES and also emphasizes the importance of cranial MRI in preeclamptic patients with neurological signs and symptoms.

Most authors believe that hypertensive encephalopathy and eclampsia share similar pathophysiologic mechanisms (17-19). The imaging findings and clinical features of postpartum eclampsia are identical to those of hypertensive encephalopathy. The pathologic process is also characterized by cerebral edema and petechial hemorrhages, especially in the parieto-occipital and occipital lobes. The spectrum of cerebral lesions in eclampsia seen with MRI varies from initially reversible areas of vasogenic edema to those that may progress to cytotoxic edema and infarction in up to a fourth of women. Eclamptic seizures might be considered as one of the symtoms of PRES in severely preeclamptic patients $(20,21)$. In the present severe preeclamptic case, sensory and motor deficits rather than seizure developed as the manifestations of PRES, which is an atypical presentation.

The widespread use of MRI technology has made PRES familiar to many clinicians. The recently described PRES classically consists of reversible vasogenic edema in the posterior circulation territories. However, when the diagnosis and treatment was delayed, conversion to irreversible cytotoxic edema leading to chronic sequela has been described. Early recognition of PRES with immediate and effective treatment of the inciting conditions - which were the patient's hypertension and seizures - allow complete resolution of the clinical picture (22). In this case, diagnosis was made without delay and treatment initiated immediately. On control examination one month after delivery, no sequela remained except for intermittent amnesia. Normalization of high blood pressure, especially if accompanied with fever, is very important and deserves particular attention. In our case, fever together with blood pressure rise during labor might have triggered the development of PRES.

In conclusion, this paper reports a severe preeclampsia case complicated with PRES. In the postpartum period of a preeclamptic woman, appropriate control of blood pressure and quick management of sudden blood pressure increases are important, as those sudden increases might trigger PRES. The physician should be aware of PRES in the postpartum period of a preeclamptic woman with neurological signs and symptoms, as prompt treatment will avoid permanent brain injury with complete resolution of clinical and imaging findings.

\section{Conflict of interest}

No conflict of interest is declared by authors.

\section{References}

1. Hinchey J, Chaves C, Appignani B, Breen J, Pao L, Wang A, et al. A reversible posterior leukoencephalopathy syndrome. N Engl J Med 1996; 334: 494-500.

2. Striano P, Striano S, Tortora F, De Robertis E, Palumbo D, Elefante A, et al. Clinical spectrum and critical care management of Posterior Reversible Encephalopathy Syndrome (PRES). Med Sci Monit 2005; 11: 549-53.

3. Negro A, Zuccoli G, Regolisti G, Mastrangeli S, Rossi E. Reversible posterior leukoencephalopathy associated with postpartum HELLP syndrome. Eur J Intern Med 2005; 16: 291-3.

4. Peng WX, Nakaii M, Matsushima T, Asakura H. Atypical case of reversible posterior leucoencephalopathy syndrome associated with puerperal HELLP syndrome. Arch Gynecol Obstet 2008; 278: 269-71.

5. Garg RK. Posterior leukoencephalopathy syndrome. Postgrad Med J 2001; 77: 24-8.

6. Kastrup O, Maschke M, Wanke I, Diener HC. Posterior reversible encephalopathy syndrome due to severe hypercalcemia. J Neurol 2002; 249: 1563-6.

7. Ay H, Buonanno FS, Schaefer PW, Le DA, Wang B, Gonzalez RG, et al. Posterior leukoencephalopathy without severe hypertension: utility of diffusion-weighted MRI. Neurology 1998; 51: 1369-76.

8. Covarrubias DJ, Luetmer PH, Campeau NG. Posterior reversible encephalopathy syndrome: prognostic utility of quantitative diffusionweighted MR images. AJNR Am J Neuroradiol 2002; 23: 1038-48. 
9. Schwartz RB, Feske SK, Polak JF, DeGirolami U, laia A, Beckner KM, et al. Preeclampsia-eclampsia: clinical and neuroradiographic correlates and insights into the pathogenesis of hypertensive encephalopathy. Radiology 2000; 217: 371-6.

10. Johansson BB. The blood-brain barrier and cerebral blood flow in acute hypertension. Acta Med Scand Suppl 1983; 678: 107-12.

11. Edvinsson L, Owman C, Siesjö B. Physiological role of cerebrovascular sympathetic nerves in the autoregulation of cerebral blood flow. Brain Res 1976; 117: 519-23.

12. Sheth RD, Riggs JE, Bodenstenier JB, Gutierrez AR, Ketonen LM, Ortiz OA. Parietal occipital edema in hypertensive encephalopathy: a pathogenic mechanism. Eur Neurol 1996; 36: 25-8.

13. Sanders TG, Clayman DA, Sanchez-Ramos L, Vines FS, Russo L. Brain in eclampsia: MR imaging with clinical correlation. Radiology 1991; 180: 475-8.

14. Bartynski WS, Boardman JF. Distinct imaging patterns and lesion distribution in posterior reversible encephalopathy syndrome. AJNR Am J Neuroradiol 2007; 28: 1320-7.

15. Servillo G, Striano P, Striano S, Tortora F, Boccella P, De Robertis E, et al. Posterior reversible encephalopathy syndrome (PRES) in critically ill obstetric patients. Intensive Care Med 2003; 29: 2323-6.
16. Krishnamoorthy U, Sarkar PK, Nakhuda Y, Mullins PD. Posterior reversible encephalopathy syndrome (PRES) in pregnancy: a diagnostic challenge to obstetricians. J Obstet Gynaecol 2009; 29: 192-4.

17. Sibai BM, Schneider JM, Morrison JC, Lipshitz J, Anderson GD, Shier $\mathrm{RW}$, et al. The late postpartum eclampsia controversy. Obstet Gynecol 1980; 55: 74-8.

18. Dahmus MA, Barton JR, Sibai BM. Cerebral imaging in eclampsia: magnetic resonance imaging versus computed tomography. Am J Obstet Gynecol 1992; 167(4 Pt 1): 935-41.

19. Roth C, Ferbert A. Posterior reversible encephalopathy syndrome: is there a difference between pregnant and non-pregnant patients? Eur Neurol 2009; 62: 142-8.

20. Amagada JO, Kondagunta H, Afshan N, Watermeyer S, Jones R. Posterior reversible encephalopathy syndrome secondary to eclampsia. J Obstet Gynaecol 2008; 28: 646-7.

21. Finocchi V, Bozzao A, Bonamini M, Ferrante M, Romano A, Colonnese C, Fantozzi LM. Magnetic resonance imaging in Posterior Reversible Encephalopathy Syndrome: report of three cases and review of literature. Arch Gynecol Obstet 2005; 271: 79-85.

22. Powell ES, Goldman MJ. Posterior reversible encephalopathy syndrome (PRES) in a thirty-six-week gestation eclamptic. J Emerg Med 2007; 33: 377-9. 